\title{
Interest Introduction of German Language and Literature in Classroom
}

\author{
Wu Ling \\ Jiangxi College Of Foreign Studies
}

\author{
Keywords: German; German language and literature; Teaching; Interest
}

\begin{abstract}
With the further development of German teaching in our country, German learners are increasing year by year, which include German majors, college or middle school students who plan to go to German-speaking countries to study and related people who use German at work as well as a large number of spontaneous German learners interested in German economy and culture.In China, English is the first foreign language for most people. They have formed a set of English thinking after many years' English study and German beginners will compare these two languages unconsciously and analyze new language phenomenon with existing English knowledge to promote their understanding to knowledge. By making use of the introduction of German language literature , this paper increase interest of the students' in German teaching .
\end{abstract}

\section{Introduction}

Interest is the best teacher, which is the same in German learning. The traditional teaching mode, namely teacher plays protagonist on the platform and the students passively accept knowledge. Sometimes this can cause unsatisfied results. As the main front of teaching implementation, classroom teaching is the basic unit of organizing teaching and the main channel to improve teaching quality. As a result, it's necessary to grasp classroom teaching in order to improve study initiative, stimulate study motivation and develop study ability.

The final target of German teaching is to cultivate German communication ability of the students. So, in the process of German teaching, it not only should teach German theory but also need to guide students to use the knowledge and skills they have learned for a wide range of language reading and communication activities and pay attention to the cultivation of cross-culture communication. According to the requirements and spirit of the syllabus, it implements the teaching oriented consciousness cultivation. It meets the requirements of college German teaching reform, good for improving teaching result and stimulates the students' subjective initiative. Guidance means the direction to guide. For teaching, guidance is to meet students' need. Students is the main body of teaching and teaching should be around the main body. The key to improve teaching is to solve the requirements of students. Finding out the problem is the premise to achieve all these matters. Any reform loses its focus and direction if the real problem can't be found.

A good teaching method can make students interested in German and create greater significance of classroom teaching. This paper describes the teaching method and improvement according to the interest introduction of German language and literature and the significance of classroom teaching.

Classroom teaching

Classroom teaching is a means widely used in teaching, which is a whole process of teachers teaching students knowledge and skills. It mainly include teachers explaining, teaching activities and all the teaching in the process of teaching. It's also called "class lecturing system ".

But there are also some disadvantages of classroom teaching:

\section{Learn According to Teaching}

Teachers often regard teaching process as a process in which the students cooperate with teachers to complete the teaching plan. This will to some extent ignores the existence of students as the main 
body. Teachers neglect the analysis to students before class and this will greatly reduced the teaching effect.

Take Books as the Orientation. Faithfully perform the teaching material . Teachers just teach according to the teaching material. Even if they find something improper in the teaching material, they dare not to solve them casually. Teaching is not creative, and creativity is the key to the success of teaching.

Sole Teaching Method. The "teaching" in traditional classroom is to repeat what the books say. Teachers just take students as the container to accept knowledge. The ideal process in classroom of teacher's teaching and students' learning is to complete the lesson plans rather than "branch off".

Sole Learning Method. Learning method is sole and passive. The learning method of students mainly embodies individuality. Teachers and students are often in a state of tension and even opposite. In class, it's rare to see interpersonal communication or different ideas or wisdom collision. The learning of students always remain passive.

\section{Creation of German Teaching}

With the development of modern technology, modern science has been applied to the traditional classroom in the scope of multimedia. In the process of teaching German, most teachers primarily use blackboard, chalk and textbooks, assisting with multimedia and PPT lecture or with both. In fact, the reason to use multimedia is on one hand it saves a lot of blackboard writing time and on the other hand, it can give students a lot of knowledge related to teaching in a short period. It broadens the students' knowledge, deepen the understanding of knowledge and improves the efficiency of classroom teaching. In actual classroom teaching, it is recommended to combining textbooks and show the students related pictures and German music. Play German news and programs via internet and when correcting the pronunciation play the video of students' own role-play. From multiple senses and perspectives to stimulate and deepen the students' impression. These not only can deepened the understanding of the course of students but also improve the interest of students to German and German culture learning.

Cultivate students' ability of using language to communicate, think, acquire and solve information. In German class, the teacher is not only the knowledge imparter but the guide of knowledge. When teaching grammar, it shouldn't blindly talk about the rules and regulations but let students to find the grammar regulations from massive examples and make comparison and summarize. Only in this way can students really learn the correct German expression , not by memorizing the grammar rules to avoid their own language. Find the characteristics of German in thinking and experiencing the difficulties of German in summarizing. Students take the initiative to enter the role and the classroom teaching will get twice the result with half the effort. Besides, German language teaching should use more practice mode of single practice, dialogue of two and multiple students in a pair. Especially for senior students, it should advocate the interactive teaching methods of students to do more reports in class and more communication between teachers and students.

\section{Atmosphere Regulation of German Classroom}

The atmosphere and environment of classroom learning directly affect the learner's mental outlook and learning motivation. The encouragement of teachers to students will greatly stimulate their interest to participate in classroom teaching.

Pay attention to the comprehensive ability such as listening, speaking, reading and writing in the process of teaching, encourage them to practice German boldly and use it in real life. In listening practice, teachers can look for proper listening materials according to students' level. Then encourage students to summarize the listening contents according to German knowledge they have learned, and express in their own language. In oral training, teachers can combine the theme of the textbook with students' reality and encourage them to create independently and make unprepared speech. For 
students in basic stage, we can properly make use of some illustrations to create situations, cultivate students' understanding ability and innovation spirit. Ask students to make up a dialogue or a story with the knowledge they have learned according to the content of the illustration. For senior students, we can ask them to do a report in combination of the current international and domestic situation or their own experience, thus to improve their logical thinking ability and language expression ability.

Respect each student, cultivate the creative character when being kind to the underachievers and it's not enough to stay on creating teaching situation. Teachers first must have the spirit of innovation, attach great importance to create easy and harmonious teaching atmosphere, respect students and pay attention to make objective and fair evaluation to the learning behavior and results of students.

\section{Conclusion}

The teaching method of classroom interest to a certain extent mobilizes the enthusiasm of learning, better solves the problems existing in previous learning, lays a solid German foundation for students, improves the comprehensive ability of using German and achieves good teaching result. At the same time, it deepens students understanding of German culture and lay a good foundation to achieve cross-culture communication.

To sum up, in German teaching, teachers should pay attention to learning situation of students and encourage their progress timely and use multimedia appropriately .Create a variety of teaching situation to stimulate students' interest in learning according to time, place and people. Then the German classroom teaching effect, German level of the students and the interest to learn German can greatly be improved. Once the students are interested in learning German, they can quickly cross the threshold. Then it lays a good foundation to German teaching and helpful to improve teaching quality.

\section{References}

[1] Belz, Julie A., and J. Reinhardt. "Aspects of advanced foreign language proficiency: Internet-mediated German language play." International Journal of Applied Linguistics 14.3(2004):324--362.

[2] Fall C J, Törcsvári A, Fiévet $\mathrm{P}$, et al. Automated categorization of German-language patent documents[J]. Expert Systems with Applications, 2004, 26(2):269-277.

[3] Machill, M., Neuberger, C., Schweiger, W., \& Wirth, W. (2004). Navigating the internet a study of german-language search engines.European Journal of Communication, 19(3), 321-347.

[4] Cerman, George O. "A Grammar of the German Language." Journal of English \& Germanic Philology 6.1(1922):164-164.

[5] Russ, C. V. J. (1994). The German language today : a linguistic introduction. Routledge.

[6] Beller, F. K. (2000). [the future of the german language in science].. Gynäkologisch -geburtshil fliche Rundschau, 40(1).

[7] Schmidt, and Johannes. "Podcasting as a Learning Tool: German Language and Culture Every Day." Unterrichtspraxis/teaching German 41.2(2008):186-194.

[8] Strech, D., \& Reimann, S. (2011). [german language physician rating sites].. Das Gesundheitswesen, 74(8-9), e61-7.

[9] Wohlert, H. S. (1984). Voice input/output speech technologies for german language learning. Unterrichtspraxis, 17(1), 76-84.

[10] Valtin, Renate. Dyslexia in the German Language. Reading and Writing Disorders in Different Orthographic Systems. Springer Netherlands, 1989:119-135.

[11] Wachman, Marvin, and C. Wittke. "The German-Language Press in America." Mississippi Valley Historical Review 62(1957). 
[12] Costa, B. Gomes Da, and B. G. D. Costa. "German Language Attainment: A Sample Survey of Universities and Colleges in the UK." Academic Aptitude (1975):101. 